\title{
EDITORIAL
}

\section{OS PROCESSOS DE REVISÃO DE ARTIGOS}

O volume que leitor tem nas mãos é resultado, como de praxe, de um longo processo de elaboração que começa com as pesquisas que dão suporte aos artigos e segue, de forma algo indeterminada, com as sucessivas leituras e menções que possam ser feitas aos trabalhos nele publicados. Uma das etapas desse percurso é a avaliação por pares, pelos revisores que tanto colaboram com a revista.

O processo de revisão dos artigos tem sido um dos pontos de maior reclamação de autores que submetem seus trabalhos à RBCE. Eles têm razão, de fato, a avaliação é demorada, chegando a vários meses em alguns casos. Trata-se de um problema de difícil solução, mas que temos tentado amenizar de diversas formas, tais como a ampliação massiva do corpo de revisores, a elaboração de estratégias de comunicação mais efetiva, a realização de orientações mais claras, detalhadas e objetivas nos formulários de avaliação. Mesmo assim, a demora ainda é grande, situação que se agrava ainda mais pelo crescimento das já numerosas submissões. Os pedidos de avaliação, bem como os constantes lembretes enviados aos revisores, têm efeito limitado em relação a muitos pesquisadores, uma vez que o encargo pouco traz de vantagens acadêmicas para seus autores, sendo nenhum o ganho pecuniário. Se as revistas, e consequentemente a área de conhecimento, dependem, para sua sobrevivência, dos revisores, então precisamos pensar coletivamente em formas de minimizar todas essas dificuldades. A RBCE não se esquiva desse processo.

Este número apresenta quinze artigos originais e uma resenha que versam sobre diferentes temas que compõem a área da Educação Física/Ciências do Esporte. O primeiro trabalho trata dos índices fisiológicos e neuromusculares determinantes da performance de corredores velocistas e meio-fundistas, e sua relação com os programas de treinamento e a performance nas corridas. $O$ artigo seguinte verifica a ativação e a co-contração muscular dos músculos tibial anterior e gastrocnêmio lateral, comparando a marcha de mulheres a partir da utilização de sapatos com 
diferentes alturas de salto e com os pés descalços. Analisando 510 atletas inscritos em competições federadas das categorias de base do futsal em Minas Gerais, o terceiro trabalho aponta para idade relativa dos jogadores como importante variável para identificação de talentos em diversas modalidades esportivas. Na sequência, são apresentados artigos que tratam do estilo de vida de acadêmicos da Educação Física de uma universidade pública de Sergipe; da variável da atenção e suas implicações na prática da vela; da comparação do equilíbrio entre deficientes visuais praticantes e não praticantes de capoeira; da existência de traços semelhantes entre algumas manifestações combativas, especialmente as geradas na diáspora africana durante a escravidão, e a capoeira. Os demais textos abordam questões relacionadas aos jogos eletrônicos que captam e virtualizam os movimentos reais de usuários, como linguagem que pode ampliar e recriar as possibilidades das práticas e vivências corporais; a produção acadêmica do campo da Educação Física na Colômbia; o ensino do esporte em projetos socioeducativos; as representações de gênero produzidas e reproduzidas pelo site Terra sobre os atletas participantes dos Jogos Olímpicos de Pequim; o futebol feminino no discurso televisivo; os programas esportivos como supostos espaços de discussão do futebol; o surgimento da natação competitiva feminina como um locus de poder simbólico que permitiu às mulheres da elite conquistar o espaço público, sem maiores resistências sociais, adequando-se ao projeto eugênico do Estado e ganhando visibilidade no contexto de uma sociedade patriarcal e conservadora. O penúltimo artigo, ao abordar o filme $O$ Destino (Fernando Vendrell, 1998), considerado como um mapa que descortinou importantes questões do cotidiano caboverdiano, discute a relação de ex-colônias com os antigos colonizadores e a migração de atletas de países economicamente menos desenvolvidos para os grandes centros, especialmente a Europa. O número finaliza com uma resenha do livro A escola e o esporte: uma história de práticas culturais (2009), de Meily Assbú Linhales, que apresenta e analisa a Educação Física e o processo de escolarização do esporte a partir da Associação Brasileira de Educação nas décadas de 1920 e 1930.

A RBCE foi contemplada, no ano passado, com recursos financeiros de apoio às publicações científicas, por parte o Conselho Nacional de Desenvolvimento Científico e Tecnológico, CNPq. Congratulamo-nos com autores, revisores, leitores, críticos, sócios e diretores do CBCE, além de equipe editorial da RBCE, todos muito importantes para que alcançássemos mais esse patamar. Esperamos fazer jus a tal reconhecimento.

Florianópolis, Vitória, março de 2012.

Alexandre Fernandez Vaz

Felipe Quintão de Almeida

Jaison José Bassani 